\title{
KEBIJAKAN PEMERINTAH DAERAH KABUPATEN DEMAK DALAM MENCIPTAKAN IKLIM INVESTASIYANG BERBASIS NILAI KEADILAN ISLAM
}

\author{
Ahmad Zaeni \\ Magister Hukum Universitas Semarang
}

\begin{abstract}
ABSTRAK
Tujuan dari penelitian ini adalah untuk mengetahui dan menganalisa kebijakan pemerintah daerah Kabupaten Demak dalam menciptakan iklim investasi yang berbasis nilai keadilan Islam. Kemiskinan bisa diatasi dengan meningkatkan pendapatan masyarakat, penanaman modal atau investasi adalah salah satu cara membuka lapangan pekerjaan yang secara otomatis mengurangi angka kemiskinan, sejauh manakah peran Pemerintah Daerah Kabupaten Demak dalam mendukung investasi permasalahan dalam penelitian ini adalahbagaimanaKebijakan Pemerintah Daerah Kabupaten Demak dalam menciptakan iklim investasi yang berbasis nilai keadilan islam suatu kajian peraturan Bupati Demak nomor 27 tahun 2013dan bagaimana problematika atas kebijakan peraturan Bupati Demak nomor 27 tahun 2013. Metode yang diguakan dalam penelitian ini merupakan spesifikasi penelitian yuridis sosiologis. Berdasarkan hasil penelitian dan analisis yang telah dilakukan dapat disimpulkan bahwa kebijakan Pemerintah Daerah Kabupaten Demak dalam menciptakan iklim investasi yang berbasis nilai keadilan islam. Problematika atas kebijakan peraturan Bupati Demak Nomor 27 Tahun 2013 yakni Faktor internal dari dalam Dinpm PTSP Kabupaten Demak Jumlah Sumber daya manusia yang terbatas, solusi yang diambil adalah dengan tetap memaksimalkan tenaga yang ada kedua, Sarana dan prasarana yang sudah terlalu lama, Faktor eksternal merupakan faktor yang berasal dari luar dalam hal ini berasal dari calon investor itu sendiri
\end{abstract}

Kata Kunci: Investasi; kebijakan; pemerintah daerah 


\title{
REGIONAL GOVERNMENT POLICY, DEMAK DISTRICT IN CREATING AN INVESTMENT CLIMATE BASED ON ISLAMIC JUSTICE VALUE
}

\author{
Ahmad Zaeni \\ Master of Law, University of Semarang
}

\begin{abstract}
The purpose of this research is to find out and analyze the policies of the local government of Demak Regency in creating an investment climate based on Islamic justice values. Poverty can be overcome by increasing community income, investment or investment is one way to create jobs that automatically reduce poverty, the extent to which the role of the Demak Regency Government in supporting investment based on the value of Islamic justice, a study of the Regent of Demak regulation number 27 of 2013 and how the problems with the policy of the Regent of Demak regulation number 27 of 2013. The method used in this study is a sociological juridical research specification. Based on the results of research and analysis that has been done, it can be concluded that the policies of the Demak Regency Government in creating an investment climate based on Islamic justice values. Problematics on the policy of Regak Regent Regulation Number 27 of 2013, namely internal factors within the Dinak PTSP Demak Regency Amount of limited human resources, the solution taken is to keep maximizing the second available power, facilities and infrastructure that have been too long, External factors are factors which comes from outside in this case comes from potential investors themselves
\end{abstract}

Keywords: Investment; policy; regional government 


\section{A. PENDAHULUAN}

Keyakinan dari Bangsa Indonesia yang dinyatakan di dalam UndangUndang dasar Negara Republik Indonesia (UUD 1945) bahwa Indonesia adalah negara kesejahteraan (welfare state). Satu di antaranya tercantum di dalam Pembukaan UUD 1945 yang secara jelas menentukan bahwa salah satu staat sidee Negara Indonesia adalah memajukan kesejahteraan umum.

Batang tubuh konstitusi UUD 1945 juga merumuskan konsepsi negara kesejahteraan ke dalam frase "kemakmuran rakyat". Adapun frase tersebut dapat diintegrasikan pada dua Ketentuan Pasal di dalam UUD 1945. Pertama, Pasal 23 ayat (1) UUD 1945 yang merupakan rezim bab Keuangan Negara menentukan bahwa: "Anggaran Pendapatan dan Belanja Negara sebagai wujud dari pengelolaan keuangan negara ditetapkan setiap tahun dengan undang-undang dan dilaksanakan secara terbuka dan bertanggung jawab untuk sebesar-besarnya kemakmuran rakyat. ${ }^{1}$

Pasal 33 Undang-undang Dasar Negara Republik Indonesia tahun 1945menggambarkan pengelolaan perekonomian sebagai usaha bersama atas asas kekeluargaan. Cabang perekonomian yang menguasai hajat hidup orang banyak dikuasai oleh negara, bumi dan air dan kekayaan alam dipergunakan untuk sebesar-besar kemakmuran rakyat. Sedangkan Pasal 34 mengatakan, fakir miskin dan anak-anak yang terlantar dipelihara oleh negara. Demikian juga Pembukaan UUD 1945, tujuan negara ini didirikan adalah untuk memajukan kesejahetraan umum.

Kemiskinan masih menjadi permasalahan yang belum terselesaikan di Indonesia. Berdasarkan angka resmi yang dikeluarkan oleh BPS Pada tahun 2012, tidak kurang dari $12 \%$ penduduk Indonesia berada dibawah garis kemiskinan yang diukur dari konsumsi perhari sebesar US\$1 (satu).Angka ini jauh lebih rendah jika dibandingkan dengan data Bank Dunia tahun 2012 yang menyatakan bahwa 50\% penduduk Indonesia termasuk kategori miskin karena pengeluaran tidak lebih dari US\$2 (Dua) per hari. Kemiskinan bisa diatasi dengan memberikan

\footnotetext{
${ }^{1}$ Indonesia (a). Undang-Undang Dasar Negara Republik Indonesia Tahun 1945. Ps. 23 ayat (1).
} 
pekerjaan yang layak dan pendidikan yang berkualitas. Lapangan kerja hanya dapat tercipta bilamana ada investasi, baik investasi pemerintah maupun dari swata asing maupun dalam negeri. Investasi swata diyakini merupakan pengerak utama bagi pembangunan ekonomi suatu daerah, dengan memperkuat pertumbuhan ekonomi dengan mendatangkan lebih banyak input ke dalam proses produksi, yang pada gilirannya akan mengangkat taraf hidup masyarakat dengan berbagai muItipIier effects lainnya.

Pemerintah Kabupaten Demak telah membuat regulasi yakni Peraturan Bupati Demak Nomor 27 Tahun 2013 Tentang Rencana Umum Penanaman Modal Kabupaten Demak, peraturan bupati ini dibuat agar investasi di Kabupaten Demak diminati investor dan pada akhirnya dapat membuka lapangan pekerjaan yang berefek domino dapat menurunkan angka kemiskinan di Kabupaten Demak, akan tetapi apakah regulasi yang sudah dibuat sejalan dan seirama dengan marwah dibuatnya Undang-undang No.25 tahun 2007 tentang Penanaman Modal, ataukah masih menghambat investasi itu sendiri, dan apakah peraturan Bupati Demak sudah mengandung regulasi investasi yang berbasis nilai keadilan Islam yang mencerminkan Demak sebagai Kota Wali. Berdasarkan uraian diatas, penulis berkeinginan untuk mengangkat dan menjadikannya dalam sebuah penelitian dengan judul "Kebijakan Pemerintah Daerah Kabupaten Demak Dalam Menciptakan Iklim Investasi Yang Berbasis Nilai Keadilan Islam (Suatu Kajian Peraturan Bupati Demak Nomor 27 Tahun 2013 Tentang Rencana Umum Penanaman Modal Kabupaten Demak)"

\section{B. PERMASALAHAN}

Berdasarkan uraian latar belakang tersebut, dapat dirumuskan permasalahan sebagai berikut :

1. Bagaimana Kebijakan Pemerintah Daerah Kabupaten Demak Dalam Menciptakan Iklim Investasi yang Kondusif sesuai dengan Peraturan Bupati Demak Nomor 27 Tahun 2013 Tentang Rencana Umum Penanaman Modal Kabupaten Demak? 
2. Bagaimana Problematika dan solusi atas kebijakan Peraturan Bupati Demak Nomor 27 Tahun 2013 Tentang Rencana Umum Penanaman Modal Kabupaten Demak.?

\section{Metode Penelitian}

1. Metode Pendekatan

Metode pendekatan yang digunakan dalam penelitian ini adalah pendekatan yuridis sosiologis yaitu penelitian yang menekankan pada gejala yang timbul dalam masyarakat dengan penelitian terhadap data primer di lapangan yang dilakukan dengan melihat gejala yang timbul dalam objek penelitian, atau terhadap kenyataan yang ada dalam masyarakat ${ }^{2}$.Dalam hal ini terkait dengan kebijakan Pemerintah Daerah Kabupaten Demak Dalam Menciptakan Iklim Investasi yang Kondusif sesuai dengan Peraturan Bupati Demak Nomor 27 Tahun 2013 Tentang Rencana Umum Penanaman Modal Kabupaten Demak dan Problematika dan solusi atas kebijakan Peraturan Bupati Demak Nomor 27 Tahun 2013 Tentang Rencana Umum Penanaman Modal Kabupaten Demak.

2. Spesifikasi Penelitian

Penulisan ini adalah termasuk dalam spesifikasi penulisan hukum empiris yang bersifat deskriptif yaitu tehnik pengumpulan data yang bersifat pemaparan, bertujuan untuk memperoleh gambaran lengkap tentang keadaan hukum yang berlaku di tempat tertentu. Suatu penelitian diskriptif dimaksudkan untuk memberikan data yang seteliti mungkin tentang manusia, keadaan atau gejala-gejala lainnya ${ }^{3}$.

Sifat penelitian yang digunakan dalam penulisan ini adalah penelitian deskriptif dengan menggunakan pendekatan kualitatif, dimana data yang diperoleh nantinya tidak berbentuk angka tetapi berupa kata-kata. Penelitian deskriptif yaitu penelitian yang dimaksudkan untuk memberikan data yang seteliti mungkin tentang manusia, keadaan, atau gejala-gejala lainnya.

${ }^{2}$ Soerjono Soekanto, Op.Cit, hlm. 52

${ }^{3}$ Ronny Hanitijo Soemitro, 1990, Methodologi Penelitian hukum dan Jurimetri, Ghalia Indonesia, Jakarta. hlm. 11 
Maksudnya adalah terutama untuk mempertegas hipotesa-hipotesa, agar dapat memperkuat teori-teori lama, atau di dalam kerangka menyusun teoriteori baru ${ }^{4}$.

3. Sumber dan Jenis Data

Di dalam penelitian ini, Jenis dan sumber data yang digunakan adalah sumber data yang sudah ada sebelumnya mengenai penanaman modal atau investasi dan juga data lapangan, yang Penulis bagi menjadi sumber data primer dan sumber data sekunder sebagai berikut :

a. Sumber Data Primer

Adalah data yang diperoleh langsung dari Pihak yang terkait dengan masalah yang diteliti. Dalam hal ini pihak yang terkait yaitu Badan Perijinan dan Penanaman Modal Kabupaten Demak., Asosiasi pengusaha Indonesia (Apindo) Kabupaten Demak dan masyarakat umum dalam hal ini dilakukan melalui riset dengan cara wawancara langsung.

b. Sumber Data Sekunder

Sumber data sekunder terdiri dari 3 (tiga) bahan hukum, ialah:

1) Bahan Hukum Primer

Yaitu bahan-bahan hukum yang mengikat, antara lain UndangUndang Dasar Negara Republik Indonesia Tahun 1945, Undang Undang No.25 tahun 2007 tentang Penanaman Modal, undang-undang No 13 tahun 2003 tentang Ketenagakerjaan, undang-undang No 2 tahun 2005 Tentang PHI, Peraturan Bupati Demak Nomor 27 Tahun 2013 Tentang Rencana Umum Penanaman Modal Kabupaten Demak.

2) Bahan Hukum Sekunder

Yaitu yang memberikan penjelasan mengenai bahan hukum primer, yaitu hasil penelitian diinstansi terkait.

3) Bahan Hukum Tersier

Yaitu bahan hukum yang memberikan petunjuk maupun penjelasan terhadap bahan hukum primer dan sekunder.

\footnotetext{
${ }^{4}$ Soerjono Soekanto,1981,Pengantar Penelitian Hukum, UI-Press, Jakarta. hlml. 10
} 
4. Teknik Pengumpulan Data

Sesuai dengan penggunaan data primer dan data sekunder dalam penelitian ini, maka pengumpulan data akan dilakukan dengan cara mengumpul, mengkaji, dan mengolah secara sistimatis bahan-bahan kepustakaan serta dokumen-dokumen yang berkaitan. Data sekunder baik yang menyangkut bahan hukum primer, sekunder dan tersier diperoleh dari bahan pustaka, dengan memperhatikan prinsip pemutakhiran dan rekavensi. Data tersebut disusun secara sistematis,.Dalam penelitian ini menggunakan studi kepustakaan (data sekunder), selain itu juga mengunakan sumber data primer yaitu dengan wawancara.

5. Metode Analisis Data

Setiap data yang bersifat teoritis baik berbentuk asas-asas, konsepsi dan pendapat para pakar hukum, termasuk kaidah atau norma hukum, akan dianalisa secara kualitatif kemudian digabungkan dengan hasil dari wawancara dengan menggunakan uraian secara deskriptif.

\section{PEMBAHASAN}

\section{Kebijakan Pemerintah Daerah Kabupaten Demak dalam Menciptakan} Iklim Investasi yang Kondusif sesuai dengan Peraturan Bupati Demak Nomor 27 Tahun 2013 Tentang Rencana Umum Penanaman Modal Kabupaten Demak

Kewenangan pemerintah kabupaten atau kota dalam penyelenggaraan penananam modal adalah pada penyelenggaraan penanaman modal yang lingkupnya berada dalam kabupaten atau kota. Hal ini secara tegas tertuang pada Pasal 30 ayat (6) UUPM, dimana dinyatakan: "Penyelenggaraan penanaman modal yang ruang lingkupnya berada dalam satu kabupaten/kota menjadi urusan pemerintah kabupaten atau kota."

Setelah dilakukan kajian secara yuridis normatif atas UUPM berkaitandengan desentralisasi . penanaman modal, maka ada beberapa analisis menarik berkaitan dengan desentralisasi penanaman modal dalam 
UUPM, diantaranya adalah: Pertama, meskipun nomenklatur desentralisasi tidak terdapat dalam UUPM, namun dalam UUPM terdapat 1 (satu) bab yang mengatur penyelenggaraan penanaman modal, dimana diatur secara tegas kewajiban dan kewenangan pemerintah, pemerintah provinsi dan Pemerintah kabupaten/kota.Kedua, kewajiban bagi pemerintah daerah untuk menjamin dan keamanan berusaha bagi pelaksana penanaman modal sebagaimana disebutkan dalam Pasal 30 ayat (1) UUPM merupakan sesuatu yang sangat memberatkan, karena Pemerintah daerah tidak memiliki aparat pengamanan. Kewajiban memberikan keamanan merupakan suatu yang bertentangan dengan Undang-undang Nomor 9 Tahun 2015, karena Undang-undang Nomor 9 Tahun 2015 secara tegas menyatakan bahwa kewenangan pemerintah pusat meliputi politik luar negeri, pertahanan, keamanan, yustisi, moneter dan fiskal nasional dan agama

Ketiga, Pemerintah pusat memiliki kewenangan yang sangat luasdalam penanaman modal. Kewenangan pemerintah pusat berdasarkan UUPMadalah: a). penanaman modal terkait dengan sumber daya alam yang tidak terbarukan dengan tingkat risiko kerusakan lingkungan yang tinggi, bidang industri yang merupakan prioritas tinggi pada skala nasional, penanaman modal yang terkait pada fungsi pemersatu dan penghubung antar wilayah atau ruang lingkupnya lintas provinsi, penanaman modal yang terkait pada pelaksanaan strategi pertahanan dan keamanan nasional, penanaman modal asing dan penanam modal yang menggunakan modal asing, yang berasal dari pemerintah negara lain, yang didasarkan perjanjian yang dibuat oleh pemerintah dan pemerintah negara lain; dan bidang penanaman modal lain yang menjadi urusan Pemerintah menurut undang-undang.

Keempat, Pemerintah provinsi dan pemerintah kabupaten/kota mempunyai kewenangan yang sangat terbatas dalam UUPM. Dimana kewenangan pemerintah provinsi adalah penyelenggaraan penanaman modal yang ruang lingkupnya lintas kabupaten kota saja dan kewenangan 
pemerintah kabupaten/kota adalah penyelenggaraan penanaman modal yang ruang lingkupnya berada dalam satu kabupaten atau kota. Secara keseluruhan kebijakan Pemerintah Kabupaten Demak telah sesuai dengan Undang-Undang No 25 Tahun 2007 tentang Penanaman Modal, hal ini sejalan dengan teori Lon L.Fuller. menurut Fuller, agar hukum (peraturan) berfungsi dengan baik, maka peraturan tersebut harus mematuhi atau mengikatkan diri secara ketat kepada 8 (delapan) syarat yang merupakan azas-azas dalam pembentukan peraturan perundang-undangan diantaranya adalah The Enactment of Contradictory Rules (tidak boleh mengandung aturan-aturan yang bertentangan satu-sama lain). Meskipun beberapa waktu yang lalu Mendagri telah membatalkan ratusan perda yang dianggap menghambat investasi, untuk Perda Kabupaten demak tidak ada yang dibatalkan. Ada beberapa cara yang dilakukan DINPM PTSP Kab.Demak untuk menarik investor diantaranya adalah :

1. Mempermudah prosedur perijinan

2. Mengadakan pameran baik tingkat regional maupun nasional

3. Melakukan pameran langsung maupun dengan media cetak

4. Melakukan sosialisasi terkait perijinan

Surat edaran Menteri Dalam Negeri Nomor 500/3231/SJ tentang tindak lanjut Peraturan Menteri Dalam Negeri Nomor 19 tahun 2017 yang pada pokoknya memerintahkan kepada Pemerintah daerah untuk melakukan pencabutan izin gangguan dan punggutan retribusi izin gangguan karena menghambat iklim investasi . Dari 64 (enam puluh empat) Perijinan hanya terdapat 7 (tujuh) yang menerapkan retribusi.

\section{Problematika dan solusi atas kebijakan Peraturan Bupati Demak Nomor} 27 Tahun 2013 Tentang Rencana Umum Penanaman Modal Kabupaten Demak

Banyak peraturan pemerintah atau keputusan presiden tidak bisa berjalan efektif karena adanya tarik-menarik kepentingan antara pemerintah pusat dan 
pemerintah daerah yang semuanya merasa paling berkepentingan atas penanaman modal di daerah. Melihat realita yang ada akhirnya pemerintah pusat melalui Kemendagri telah membatalkan perda yang diangaap menghambat investasi di daerah. Dalam membahas atau mengidentifikasi kendala perijinan penanaman modal di Indonesia, ada tiga hal yang perlu dipahami. Pertama, ijin investasi tidak bisa dilihat sebagai sesuatu yang berdiri sendiri, tetapi harus menjadi satu paket dengan ijin-ijin lain yang secara langsung maupun tidak langsung mempengaruhi kegiatan usaha atau menentukan untung ruginya suatu usaha sejumlah Undang-undang dan peraturan menteri yang sangat berpengaruh terhadap kelancaran proses mulai dari awal investasi hingga menjadi suatu perusahaan yang siap beroperasi dan menghasilkan keuntungan

Hambatan yang dihadapi Dinpm PTSP Kabupaten Demak dalam menarik investasi dapat dibagi dalam 2 (dua) faktor yaitu:

\section{Faktor eksternal}

Faktor eksternal merupakan faktor yang berasal dari luar dalam hal ini berasal dari calon investor itu sendiri, investor merasa mengurus perijinan masih sulit sedangkan persyaratan mereka memang tidak lengkap dan adapula investor yang mengurus perijinan tidak datang sendiri akan tetapi lewat biro jasa sehingga yang semula murah dan cepat menjadi berbiaya sebagai upah untuk biro jasa tersebut

\section{Faktor Internal}

Faktor internal adalah faktor yang berasal dari dalam Dinpm PTSP Kabupaten Demak diantaranya adalah:

a. Jumlah Sumber daya manusia yang terbatas, sehingga beban kerja lebih banyak, solusi yang diambil adalah dengan tetap memaksimalkan tenaga yang ada

b. Sarana dan prasarana seperti komputer dan printer yang sudah terlalu lama sehingga sering eror, solusi yang diambil adalah dengan 
mengajukan anggaran kepada Pemerintah daerah untuk peremajaan sarana dan prasarana tersebut.

Di sisi lain Pemerintah Kabupaten Demak harus mengoptimalkan Organisasi Perangkat Daerah yang tergabung dalam tim teknis Perizinan sesuai Keputusan Bupati Demak Nomor 570/8/Tahun 2017 untuk memaksimalkan peran masing-masing agar pelayanan perijinan bisa lebih efektif dan efisien teori Sistem Hukum Lawrence M.Friedman merupakan teori yang relevan dengan penguatan kelembagaan tim teknis yakni struktur hukum yang mengacu pada bentuk dan kedudukan pranata hukum yang terdapat dalam sistem hukum hubungan antar lembaga tinggi negara. Komponen struktur dari suatu sistem hukum mencakup berbagai institusi (dinas) yang diciptakan oleh sistem hukum tersebut dengan berbagai macam fungsinya dalam mendukung bekerjanya sistem hukum tersebut. seperti fasilitas jaringan air untuk industri, karena selama ini belum ada jaringan air Perusahaan Daerah Air Minum Kabupaten Demak yang memasok kebutuhan perusahaan sehingga perusahaan harus mencari alternatif pasokan air bersih sendiri ${ }^{5}$.

\section{E. PENUTUP}

Kebijakan Pemerintah Daerah Kabupaten Demak dalam menciptakan iklim investasi yang kondusif sudah diformulasikan dengan baik hal ini tercermin dalam peraturan Bupati Demak Nomor 27 Tahun 2013 dimana perpub tersebut telah sesuai dengan kebijakan perundangan - undangan nomor 25 tahun 2007 tentang penanaman modal karena dala penyusunan Perbup tersebut berpedoman dengan peraturan perundang-undangan, hal ini terlihat dengan diberikannya insentif dan kemudahan investor untuk berinvestasi di Kabupaten Demak. Keputusan Bupati Demak Nomor 570/8/Tahun 2017 tentang pembentukan Tim Teknis Perizinan Paada Dinas Penanaman modal dan pelayanan terpadu satu Pintu menunjukkan keseriusan pemerintah Kabupaten Demak untuk menjadikan demak daerah ramah investasi.Kabupaten Demak juga sudah menjalankan Surat edaran Menteri Dalam

${ }^{5}$ Wawancara dengan Keua Apindo Demak, M.H. Ilyas 10 Februari 2018 
Negeri Nomor 500/3231/SJ tentang tindak lanjut Peraturan Menteri Dalam Negeri Nomor 19 tahun 2017 yang pada pokoknya memerintahkan kepada Pemerintah daerah untuk melakukan pencabutan izin gangguan dan punggutan retribusi izin gangguan, karena menghambat iklim investasi, Problematika yang atas kebijakan Peraturan Bupati Demak Nomor 27 Tahun 2013 Tentang Rencana Umum Penanaman Modal Kabupaten Demak terbagi dalam dua faktor yakni faktor internal dan faktor eksternal, Faktor internal adalah faktor yang berasal dari dalam Dinpm PTSP Kabupaten Demak diantaranya pertama Jumlah Sumber daya manusia yang terbatas, sehingga beban kerja lebih banyak, solusi yang diambil adalah dengan tetap memaksimalkan tenaga yang ada kedua, Sarana dan prasarana seperti komputer dan printer yang sudah terlalu lama sehingga sering eror, solusi yang diambil adalah dengan mengajukan anggaran kepada Pemerintah daerah untuk peremajaan sarana dan prasarana tersebutFaktor eksternal merupakan faktor yang berasal dari luar dalam hal ini berasal dari calon investor itu sendiri, investor merasa mengurus perijinan masih sulit sedangkan persyaratan mereka memang tidak lengkap dan adapula investor yang mengurus perijinan tidak datang sendiri akan tetapi lewat biro jasa sehingga yang semula murah dan cepat menjadi berbiaya sebagai upah untuk biro jasa tersebut.

\section{Daftar Pustaka}

\section{Buku}

Aminuddin Ilmar .2004.Hukum Penanaman Modal di Indonesia, Kencana, Jakarta. Badan Pusat Statistik dan World Bank Institute,Januari 2002 Dasar-Dasar Analisis Kemiskinan, BPS, Jakarta,

Bahar Ujang, 2009, Otonomi Daerah Terhadap Pinjaman Luar Negeri, Antara Teori dan Praktik. PT. Indeks Permata Puri Media. Jakarta.

Curry, Jeffry Edmund. 2001, Memahami Ekonomi Internasional, Memahami Dinamika Pasar Global, Penerbit PPM, Jakarta

Dirdjosisworo, Soedjono. 1999, Hukum Perusahaan Mengenai Penanaman Modal di Indonesia, cetakan Pertama, CV. Mandar Maju

H.A.W. Wijaya 2004, Otonomi Daerah dan Daerah Otonom, PT Raja Grafindo 
Persada, Jakarta.

Hartono, Sri Redjeki. 2007, Hukum Ekonomi Indonesia, cetakan Pertama, Bayumedia Publishing, Malang

Hiil Hall, 1989, Investasi Asing dan Industrialisasi di Indonesia, LP3ES, Jakarta,

Ilmar Aminuddin, 2007, Hukum Penanaman Modal Di Indonesia, Kencana, Jakarta.

Jatmika, Sidik. 2001, Otonomi Daerah, Perspektif Hubungan Internasional, Biagraf Liberty, Yogyakarta.

Kartadjoemana, H.S. 1996, GATT DAN WTO, Sistem, Forum dan Lembaga Internasional dibidang Perdagangan, cetakan Pertama, Universitas Indonesia

LPEM-FEUI 2001, “Construction of Regional Index of Doing Business”, Laporan Akhir, Jakarta.

Mudrajad Kuncoro (2004), Otonomi dan Pembangunan Daerah: Reformasi, Perencanaan, Strategi, dan Peluang, Penerbit Erlangga, Jakarta

Rokhmatussa'dyah, Ana dan Suratman, 2010, Hukum Investasi dan PasarModal, Jakarta : Sinar Grafika.

Sembiring, Sentosa, 2010, Hukum Investasi, Bandung : Nuansa Aulia.

Sihombing, Jongker, 2009, Hukum Penanaman Modal Di Indonesia, Bandung : PT.Alumni.

Swasembada 2004, “Apa Siapa Macan-macan Bisnis Daerah”, Edisi Khusus, No 8/XX/15-28 April. WEF (2007).

\section{Jurnal}

Tulus Tahi Hamonangan Tambunan, Dkk. 2007, Jurnal Hukum Dan Bisnis Volume 24-No 4 Tahun 2007. ISSN: 0852/4912. Yayasan Pemgembangan Hukum Bisnis: Jakarta.

\section{Undang-Undang}

Undang-Undang Dasar Negara Republik Indonesia 1945

Undang-undang No 13 tahun 2003 tentang Ketenagakerjaan,

Undang-undang No 2 tahun 2005 Tentang PHI,

Undang-Undang Nomor 25 Tahun 2007 Tentang Penanaman Modal.

Undang-Undang Nomor 9 Tahun 2015 Tentang Pemerintahan Daerah

Perbup Demak Nomor 27 Tahun 2013 Tentang Rencana Umum Penanaman Modal Kabupaten Demak

\section{Internet}

http://ekonomi.kompas.com/read/2016/12/20/181701126/paket.kebijakan.ekonomi. lengkap.tetapi.minim.implementasi

http://setkab.go.id/investasi-dan-pembangunan-ekonomi/ 
Kebijakan Pemerintah Daerah Kabupaten Demak Dalam Menciptakan Iklim Investasiyang Berbasis Nilai Keadilan Islam

Ahmad Zaeni

e-ISSN : 2621-4105

https://finance.detik.com/berita-ekonomi-bisnis/3015060/dampak-paket-kebijakanekonomi-jokowi-butuh-waktu-panjang

Smbr http: //edubuku.com/ 2016/04/12 /pandangan-islam-tentang-investasi-2/ www.kppod.org 